\title{
Heart rate turbulence in patients after primary percutaneous coronary intervention and fibrinolytic treatment for acute myocardial infarction
}

\author{
Isman Firdaus, Yoga Yuniadi,Cholid Tri Tjahjono, Harmani Kalim, Muhammad Munawar
}

\begin{abstract}
Abstrak
Turbulensi laju jantung (heart rate turbulence [HRT]) baru-baru ini dianggap sebagai prediktor terbaru paling kuat untuk terjadinya kematian mendadak (sudden cardiac death [SCD]) melebihi prediktor lain yang telah ada sebelumnya. Pasien penyakit jantung koroner yang menjalani reperfusi koroner ternyata memberikan hasil HRT lebih baik dan hal ini mencerminkan pulihnya respon baroreseptor.Penelitian ini akan membandingkan nilai turbulence onset (TO) dan turbulence slope(TS) pada dua jenis reperfusi (PCI dan fibrinolitik) Subjek menjalani monitoring EKG selama 24 jam setelah dilakukan revaskularisasi. TO ditentukan dengan cara mengukur perubahan relatif dua interval RR irama sinus setelah ekstrasistol ventrikel dan dua RR interval terakhir sebelum ekstrasistol ventrikel. TS dihitung dengan dengan mengukur slope maksimum yang dibuat tiap 5 buah RR interval. Terdapat 13 pasien (usia rata-rata $56 \pm 9$ tahun) yang memenuhi syarat untuk ikut dalam penelitian. Sepuluh pasien menjalani fibrinolitik dan tiga pasien menjalani PCI. Terdapat perbedaan bermakna nilai TO antara kelompok PCI dan fibrinolitik $(-3,3+1,7 \%$ vs $-0,2+0,9 \% ; P=0,03)$. Terdapat kecenderungan kelompok PCI memberikan nilai TS yang lebih baik dibanding kelompok fibrinolitik, walaupun secara statistik tidak signifikan ( 7,7 \pm 4,4 msec/RR interval vs 3,4 \pm 2,6 msec/RR interval; $P=0,056)$. Disimpulkan bahwa subjek dengan STEMI akut yang menjalani PCI mempunyai nilai TO yang lebih baik dibanding subjek yang menjalani terapi fibrinolitik. (Med J Indones 2007; 16:19-24)
\end{abstract}

\begin{abstract}
Heart rate turbulence (HRT) as novel predictor of sudden cardiac death were superior to all other presently available indicators. HRT significantly was improves after successful reperfusion reflecting rapid restoration of baroreceptor response. We investigated turbulence onset (TO) and turbulence slope (TS) values among patients with acute ST-elevation myocardial infarction (STEMI) underwent revascularization by means of primary PCI or fibrinolytic. We hypothesized that the values of TO and TS were different in two kinds of revascularization treatment. The subjects underwent 24 hours ECG recording after revascularization therapy. TO was quantified by the relative change of the first two sinus $R R$ intervals following a ventricular premature beat $(V P B)$ and the last two sinus $R R$ intervals before the VPB. TS was quantified by the maximum positive slope of a regression line assessed over any sequence of five subsequent sinus rhythm $R R$ intervals within the first two sinus rhythm intervals after a VPB. Thirteen patients (mean of age $56 \pm 9$ years old) who underwent revascularization treatment of acute STEMI were eligible as subject of this study.Ten patients underwent fibrinolytic therapy and three patients underwent primary PCI. TO value was significantly different between PCI group and fibrinolytic group $(-3.3 \pm 1.7 \%$ vs $-0.2 \pm$ $0.9 \% ; P=0.03)$. The Primary PCI group has better outcome on turbulence slope value (TS) than fibrinolytic group but not significance $(7.7 \pm 4.4 \mathrm{msec} / R R$ interval vs $3.4 \pm 2.6 \mathrm{msec} / \mathrm{RR}$ interval; $P=0.056)$. In conclusion, TO was better in acute STEMI patient undergone PCI compare to that undergone fibrinolytic therapy. (Med J Indones 2007; 16:19-24)
\end{abstract}

Keywords: heart rate turbulence, revascularization, myocardial infarction

Recently, the role of HRT as a novel predictors of sudden cardiac death was believed to be superior to all other available indicators. ${ }^{1}$ In the normal autonomic response, sinus rhythm exhibits a characteristic pattern of early acceleration and subsequent deceleration after

Department of Cardiology and Vascular Medicine, Faculty of Medicine University of Indonesia, National Cardiovascular Center Harapan Kita, Jakarta, Indonesia single ventricular premature beat (VPB). ${ }^{2,3}$ These fluctuations (termed heart rate turbulence, HRT) were characterized by two numerical parameters, termed turbulence onset (TO) and slope (TS). One of the mechanisms proposed for the genesis of HRT is the alteration in the baroreceptor reflex elicited by the small drop of the arterial pressure due to the VPC. ${ }^{4,5,6}$

Barthel et al recently published the first prospective study (ISAR-HRT) to validate HRT in a large cohort 
of the reperfusion era. This study showed a 6-fold risk of death within the first 2 years after myocardial infarction. HRT identified high-risk subgroups in patients with left ventricular ejection fraction $\leq 30$ and $>30 \% .{ }^{2,8}$ In both subgroups, the combination of an abnormal TO and an abnormal TS, was a significant and independent predictor of death.

In the reperfusion era, primary percutaneous coronary intervention (PCI) and fibrinolytic treatment has been established as available management for acute ST elevation myocardial infarction (STEMI). ${ }^{8}$ Bonnemeier et al reported that HRT significantly improved after successful reperfusion in STEMI patients reflecting rapid restoration of baroreceptor response. ${ }^{9}$

The aim of the study was to elaborate the HRT values of acute STEMI patient undergone PCI and fibrinolytic therapy as methods of revasculrization.

\section{METHODS}

Subjects

The study population was derived from Emergency Room National Cardiovascular Center Harapan Kita Jakarta who were diagnosed as acute STEMI from January to February 2006. They were divided into two groups according to reperfusion treatment (primary PCI or fibrinolytic). Acute STEMI was defined as patients with ST-segment elevation, i.e. new ST-segment elevation at the $\mathrm{J}$ point with the cut-off points $\geq 0.2$ $\mathrm{mV}$ in $\mathrm{V} 1$ through $\mathrm{V} 3$ and $\geq 0.1 \mathrm{mV}$ in other leads or new LBBB. ${ }^{10}$

Participant with cardiac arrhythmia, non-ST elevation, frequent ventricular extra systole, heart failure and age more than 75 years old were excluded.

Informed consent was given before primary PCI or fibrinolytic procedure. Clinical characteristics (age, sex, past medication, lipid profile, X-ray, left ventricular ejection $[\mathrm{EF}]$ ) and $\mathrm{CAD}$ risk factors (diabetes, hypertension, obesity, smoking, and family history) were evaluated. One day after revascularization

\section{Quantification of HRT}

The 24-hour ECG monitoring was performed in order to analize the HRT. HRT was visualized after averaging of ten ventricular premature contraction (VPC) sequences in a 24-hour ECG monitoring. Two numeric of HRT (TO and TS) were averaged and quantified by Microsoft Excel program version 2003. TO was defined as difference between the mean of the two sinus RR intervals after ventricular premature beat (VPB) and the last two sinus RR intervals before VPB divided by the mean of the last two sinus RR intervals before VPB (see figure 1). ${ }^{1}$

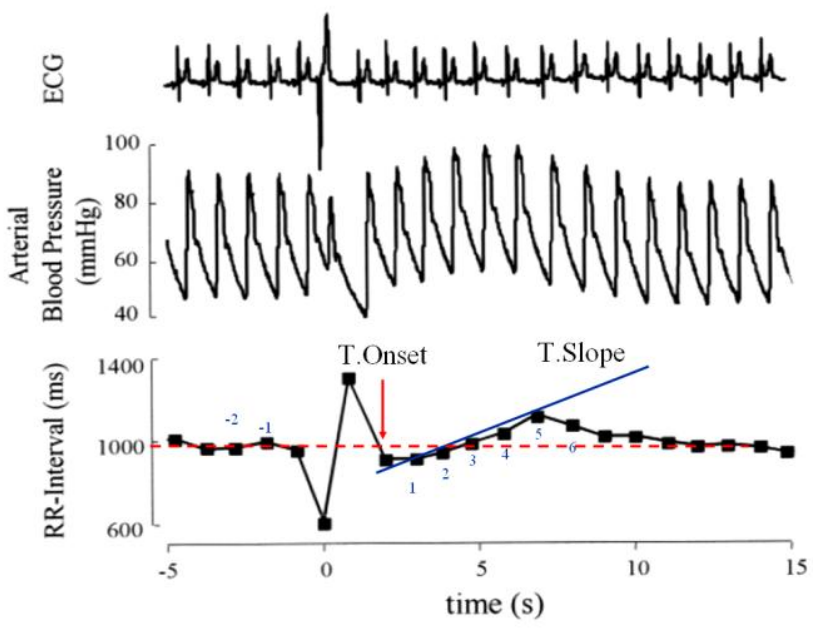

Figure 1. Quantification of HRT. TO was defined as difference between the mean of the two sinus RR intervals after ventricular premature beat $(V P B)$ and the last two sinus $R R$ intervals before $V P B$ divided by the mean of the last two sinus $R R$ intervals before VPB.TS is the maximum positive slope of a regression line assessed over any sequence of 5 subsequent sinus rhythm RR intervals.

$$
\mathrm{TO}=\frac{\left(\mathrm{RR}_{1}+\mathrm{RR}_{2}\right)-\left(\mathrm{RR}_{-2}+\mathrm{RR}_{-1}\right)}{\left(\mathrm{RR}_{-2}+\mathrm{RR}_{-1}\right)} \times 100 \%
$$

TO more than $0 \%$ corresponds to sinus rhythm deceleration after a VPB and TO less than 0\% corresponds to sinus rhythm acceleration after a VPC. The optimal dichotomy for TO is $0 \%{ }^{3}$

The subsequent deceleration of heart rate is quantified by the steepest regression line between the RR interval count and duration. The corresponding parameter is termed TS. TS is the maximum positive slope of a regression line assessed over any sequence of 5 subsequent sinus rhythm RR intervals within the first 15 sinus rhythm RR intervals after a VPC. The value of TS is expressed in milliseconds per RR interval. The optimal dichotomy for TS is $2.5 \mathrm{~ms}$ per RR interval (beat). ${ }^{3}$ 


\section{Statistic analysis}

Continuous variables are presented as means \pm SD. For descriptive purposes, we divided the study population into groups according to early revascularization modality, primary PCI and fibrinolytic treatment. The differences between the groups were tested by student's test. All analyses were performed using the SPSS system version 12 . $p$ value $<0.05$ was considered as statistically significant.

\section{RESULTS}

Of the 20 eligible patients who underwent revascularization only 13 patient met our study criteria. Five patients did have any VPB. Of the 13 patients, 10 patients underwent fibrinolytic therapy and 3 patients underwent primary PCI. There were no differences between two groups on baseline characteristics.

The dominant risk factors in both of groups are smoker (53\%) and hypertension (53\%) with less diabetic subject $(38.5 \%)$. Laboratory findings including high density lipoprotein, low density lipoprotein, and triglyseride serum level showed abnormal value in both of groups but not significantly difference. In both groups, the left ventricular systolic function was normal as reflected by ejection fraction values (mean $48 \pm 12 \%)($ Table 1$)$.

Table 1. Baseline Characteristics

\begin{tabular}{|c|c|c|c|c|}
\hline Variable & Value & Fibrinolytic & Primary PCI & $P$ value \\
\hline $\mathrm{N}$ & 13 & $10(76.9)$ & $3(23.1)$ & \\
\hline Age (years) & $56 \pm 9$ & $58 \pm 9$ & $47 \pm 4$ & 0.496 \\
\hline \multicolumn{5}{|l|}{ Sex } \\
\hline Male (\%) & $8(61.5)$ & $6(60)$ & $2(66.7)$ & 0.851 \\
\hline Female $(\%)$ & $5(38.5)$ & $4(40)$ & $1(33.3)$ & 0.851 \\
\hline \multicolumn{5}{|l|}{ Risk factors for $C A D$} \\
\hline Smoker $(\%)$ & $7(53.8)$ & $5(50)$ & $2(66.7)$ & 0.646 \\
\hline Hypertension (\%) & $7(53.8)$ & $5(50)$ & $2(66.7)$ & 0.646 \\
\hline Dislipidemia (\%) & $6(46.2)$ & $5(50)$ & $1(33.3)$ & 0.648 \\
\hline Diabetes $(\%)$ & $5(38.5)$ & $4(40)$ & $1(33.3)$ & 0.851 \\
\hline Familial history (\%) & $2(15.4)$ & $1(10)$ & $1(33.3)$ & 0.368 \\
\hline Without Diabetes (\%) & $8(61.5)$ & $6(60)$ & $2(66.7)$ & 0.633 \\
\hline HDL (mg/dl) & $38 \pm 9$ & $37 \pm 9$ & $40 \pm 13$ & 0.684 \\
\hline LDL (mg/dl) & $125 \pm 30$ & $126 \pm 36$ & $120 \pm 6$ & 0.794 \\
\hline $\mathrm{TG}(\mathrm{mg} / \mathrm{dl})$ & $198 \pm 130$ & $193 \pm 143$ & $215 \pm 116$ & 0.813 \\
\hline GDS (mg/dl) & $191 \pm 89$ & $203 \pm 93$ & $130 \pm 27$ & 0.313 \\
\hline Ejection Fraction (\%) & $48 \pm 12$ & $47 \pm 12$ & $54 \pm 18$ & 0.487 \\
\hline \multicolumn{5}{|l|}{ Onset of STEMI } \\
\hline Less than 12 hours & $11(84.6)$ & $8(80)$ & $3(100)$ & 0.443 \\
\hline More than 12 hours & $2(15.4)$ & $2(20)$ & $0(0)$ & 0.443 \\
\hline \multicolumn{5}{|l|}{ Location of infarction } \\
\hline Anterior & $9(69.2)$ & $9(90)$ & $1(33.3)$ & 0.01 \\
\hline Inferior & $4(30.8)$ & $1(10)$ & $2(66.7)$ & 0.01 \\
\hline \multicolumn{5}{|c|}{ Cardio-thoraxcic ratio (CTR) on chest $X$-ray } \\
\hline More than $50 \%$ & $8(61.5)$ & $4(40)$ & $1(33.3)$ & 0.851 \\
\hline Less than $50 \%$ & $5(38.5)$ & $6(60)$ & $2(66.7)$ & 0.851 \\
\hline
\end{tabular}


All of subjects who admitted to emergency room with the onset of infarction less than 12 hours underwent primary PCI. On the ECG examination, anterior wall was the most common site of infarction in fibrinolytic subject $(90 \%)$ but less in primary PCI $(33.3 \%)$. The day after early revascularization, HRT analysis was performed. TO values was significantly different between primary PCI and fibrinolytic groups $(-3.3 \pm$ $1.7 \%$ vs $-0.2 \pm 0.9 \% ; \mathrm{p}=0.03)$ as shown in table 2 and figure 2. The primary PCI group has better tendency on turbulence slope value (TS) than fibrinolytic group but not significant $(7.7 \pm 4.4 \mathrm{msec} / \mathrm{RR}$ interval vs $3.4 \pm 2.6 \mathrm{msec} / \mathrm{RR}$ interval; $\mathrm{p}=0.056$ ).

Table 2. Heart rate turbulence in fibrinolytic and primary PCI groups

\begin{tabular}{lcccc}
\hline $\begin{array}{l}\text { Heart rate } \\
\text { turbulence }\end{array}$ & $\begin{array}{c}\text { All } \\
\text { groups }\end{array}$ & Fibrinolytic & $\begin{array}{c}\text { Primary } \\
\text { PCI }\end{array}$ & $\begin{array}{c}\mathrm{P} \\
\text { Value }\end{array}$ \\
\hline $\mathrm{N}$ & 13 & $10(76.9)$ & $3(23.1)$ & \\
& & & & \\
$\begin{array}{c}\text { Turbulence } \\
\text { Onset (\%) }\end{array}$ & $-0.9 \pm 2.3$ & $-0.2 \pm 1.9$ & $-3.3 \pm 1.7$ & 0.037 \\
$\begin{array}{c}\text { Turbulence Slope } \\
\text { (ms/beat) }\end{array}$ & $4.4 \pm 3.4$ & $3.4 \pm 2.6$ & $7.7 \pm 4.4$ & 0.056 \\
& & & & \\
\hline
\end{tabular}

Turbulen Onset after revosculcrization

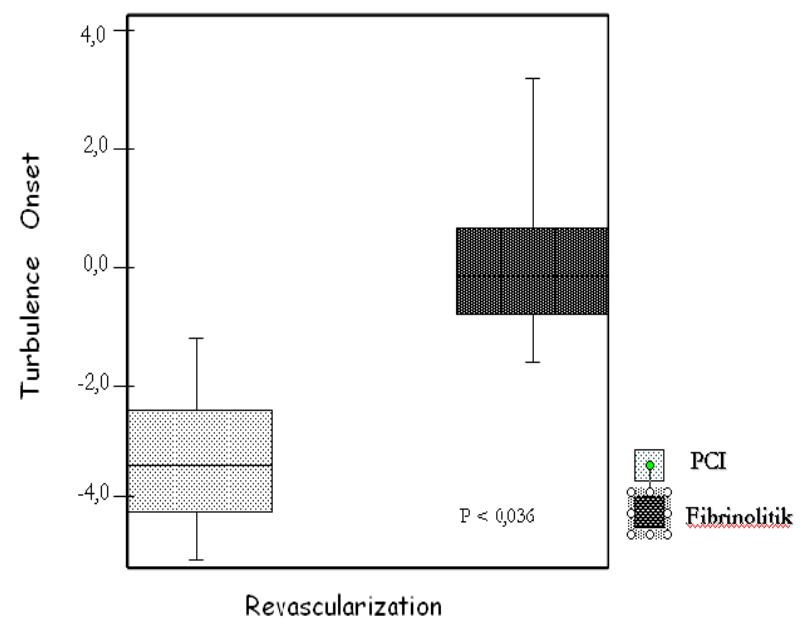

\section{DISCUSSION}

This study showed that TO values was better in acute STEMI patients undergone primary PCI compare to patients undergone fibrinolytic therapy. TO reflected autonomic response of sinus rhythm acceleration after a VPB. Previous report by Bonnemeier et al shown that the improvement of HRT after successful reperfusion reflected rapid restoration of baroreceptor response. They demonstrated that TS significantly increased and TO significantly decreased in patients with TIMI 3 flow after PCI, whereas there were no significant alterations of TO and TS in patients with TIMI 2 flow. The persistent impairment of HRT after PCI in patients with TIMI 2 flow indicates a sustained blunted baroreflex response and may reflect a more severe microvascular dysfunction. ${ }^{9}$

Comparing with fibrinolytic treatment, primary PCI was better on restoration of heart rate turbulence reflecting baroreceptor response integrity. This result did not reflect patency of the coronary vessels because TIMI flow as assessment of revascularization was not observed in this study, especially in fibrinolytic group. There is no previous data reporting HRT response after fibrinolytic treatment for acute STEMI. Fluctuation of RR intervals after VPC among two groups of reperfusion are represented in figure 3. Fibrinolitic group was less RR interval fluctuation than PCI group, quantified by TO and TS values.

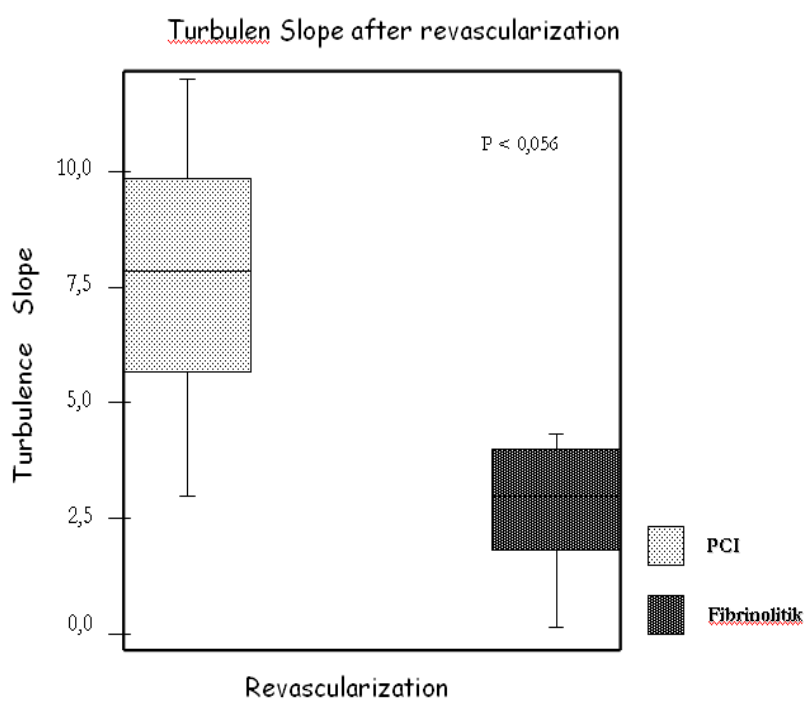

Figure 2. Heart rate turbulence profile between primary PCI and fibrinolytic treatment 


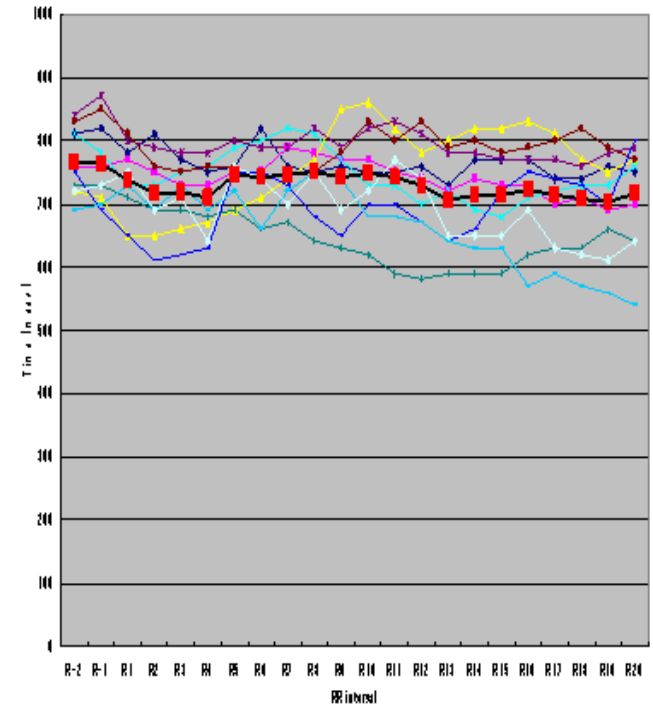

(a)

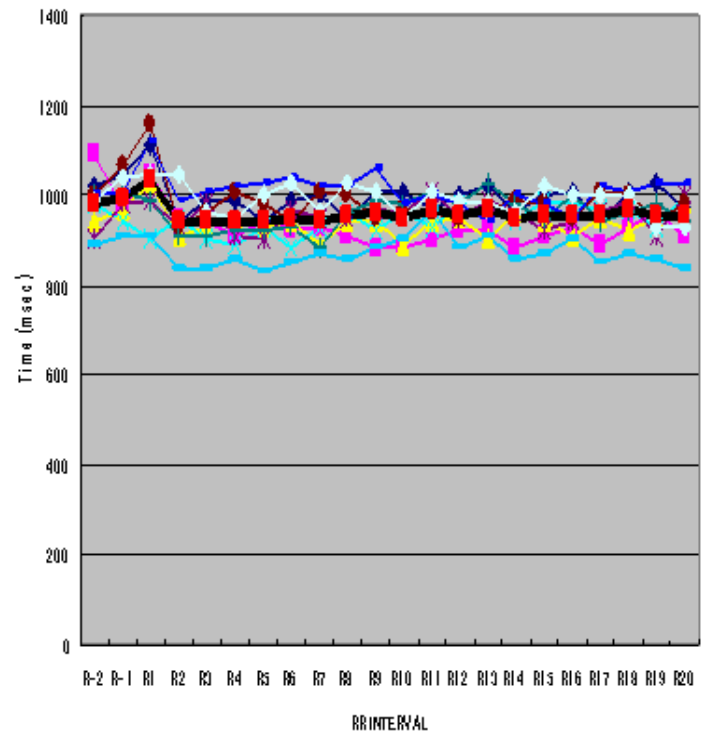

(b)

Figure 3. Heart rate turbulence (HRT) in patient with acute STEMI after primary $P C I($ a) and fibrinolytic treatment (b).Beat to beat oscilation after single ventricular premature complex were quantified with two HRT parameters, turbulence onset and turbulence slope.

Although not statistically significance, the TS of primary PCI group tend to be higher than fibrinolytic group. The number of participant enrolled in this study might be the possible explanation. The difference of turbulence slope value was not significant among two groups but there was tendency for significance. We estimated that the result will be significant if the number of participant enrolling the study were increased.

This study has some limitations. Site and onset of infarction between primary PCI and fibrinolytic groups were different. The anterior infarction was more frequent in fibrinolytic group than PCI group. Primary PCI group demonstrated earlier onset than that of fibrinolytic group.

This is a preliminary study for evaluation of heart rate turbulence after early revascularization. Abnormal HRT leads to increased mortality rate due to sudden cardiac death in the future. Intervention strategies for repairing heart rate turbulence are very important to prevent complication after myocardial infarction.

\section{CONCLUSION}

Early revascularization by primary PCI has better outcome on baroreflex sensitivity than fibrinolytic treatment after acute ST-elevation myocardial infarction as it was shown by HRT indicators. Revascularization strategies for restoring autonomic function very important to prevent complication.

\section{REFERENCES}

1. Schmidt $G$, Malik $M$, Barthel $P$, et al. Heart rate turbulence after ventricular premature beats as a predictor of mortality after acute myocardial infarction. Lancet. 1999;353:1390-6

2. Watanabe M. Heart rate turbulence: a Review. Indian Pacing Electrophysiol Journal. 2003;3:10-22

3. Welch W, Smith M, Rea R, Bauernfeind R, et al. Enhancement of sympathetic nerve activity by single premature ventricular beats in humans. J Am Coll Cardiol. 1989;13:69-75

4. Malik M, Wichterle W, Schmidt G. Autonomic modulation of the heart: heart rate turbulence. G Ital Cardiol. 1999;29:65-9.

5. Marine J, Watanabe M, Smith T, Monahan K. Effect of atropine on heart rate turbulence. Am J Cardiol. 2002; 89:767-9.

6. Mrowka R, person P, Theres H, Patzak A. Blunted arterial baroreflex causes 'pathological' heart rate turbulence. Am J Physiol regulatory Integrative Comp Physiol. 2000; 279: R1171-5.

7. Barthel P, Scheneider R, Bauer A, et al. Risk stratification after acute myocardial infarction by heart rate turbulence. Circulation. 2003;108:1221-6

8. Rogers WJ, Canto JG, Lambrew CT, et al. Temporal trends in the treatment of over 1.5 million patients with myocardial infarction in the US from 1990 through. 1999: 
the National Registry of Myocardial Infarction 1, 2 and 3. J Am Coll Cardiol. 2000;36:2056-63.

9. Bonnemeier H, Wiegand U, Friedlbinder J, et al. Reflex cardiac activity in ischemia and reperfusion: Heart rate turbulence in patients undergoing direct percutaneous coronary intervention for acute myocardial infarction. Circulation. 2003; 108:958-64.
10. Werf F, Ardissino D, Betriu A, et al. Management of acute myocardial infarction in patients presenting with ST-segment elevation. European Heart Journal. 2003;24: 28-66. 